\title{
Judgement Day in Heritage Hell
}

\author{
Karl, Raimund
}

\section{Historic Environment - Policy and Practice}

\author{
DOI: \\ 10.1080/17567505.2018.1463084
}

Published: 01/09/2018

Peer reviewed version

Cyswllt i'r cyhoeddiad / Link to publication

Dyfyniad o'r fersiwn a gyhoeddwyd / Citation for published version (APA):

Karl, R. (2018). Judgement Day in Heritage Hell: Heritage Practice, Policy, and the Law in Austria (and Beyond). Historic Environment - Policy and Practice, 9(2), 128-149. https://doi.org/10.1080/17567505.2018.1463084

\footnotetext{
Hawliau Cyffredinol / General rights

Copyright and moral rights for the publications made accessible in the public portal are retained by the authors and/or other copyright owners and it is a condition of accessing publications that users recognise and abide by the legal requirements associated with these rights.

- Users may download and print one copy of any publication from the public portal for the purpose of private study or research.

- You may not further distribute the material or use it for any profit-making activity or commercial gain

- You may freely distribute the URL identifying the publication in the public portal ?
}

Take down policy

If you believe that this document breaches copyright please contact us providing details, and we will remove access to the work immediately and investigate your claim. 


\title{
Judgement Day in Heritage Hell
}

\author{
Heritage practice, policy, and the law in Austria (and beyond)
}

\author{
Raimund Karl \\ Bangor University
}

\begin{abstract}
Two recent higher court findings from Austria show how the Austrian National Heritage Agency [BDA] has misinterpreted and misapplied the provisions of $\S 11$ (1) Austrian Monument Protection Law. While the BDA has maintained for decades that consent is required under $\S 11$ (1) for any fieldwork, even surface surveys, regardless of whether archaeology is known, legal challenge has established that neither is the case. Rather, it appears that consent under $\S 11$ (1) is only required where there is evidence that significant archaeology will be found during the fieldwork. Furthermore, $\S 11$ (1) only applies to sub-surface fieldwork or under-water evidence. As a consequence, as many as c.10,000 permits may have been granted illegally, with potentially costly conditions attached. This paper examines the court findings, their consequences for Austrian archaeological heritage management, the reasons why the BDA misinterpreted the law and reflects on the wider implications.
\end{abstract}

Keywords: Austria, monuments protection law, archaeology, fieldwork permit, court findings

\section{Introduction}

How access to archaeological evidence in situ for purposes of research [fieldwork] is managed varies between countries; but generally sits somewhere between two extremes.

The first could be described as the 'German' or 'national patrimony' model. ${ }^{1}$ Access rights are managed restrictively, to the extent that any fieldwork in situ is only permitted by license or permit issued by a state (or national) heritage agency and typically restricted to archaeology graduates. In extreme cases, a heritage agency (or more precisely, its lawyers in legal commentaries) may claim legal privilege for the state through its heritage agency to conduct any research in situ. 'Private' fieldwork is generally prohibited and is only permitted in exceptional cases. ${ }^{2}$

The second is the 'British' or 'social license' model. ${ }^{3}$ Access rights are managed liberally under this model, with an official permit only required for works which affect designated archaeological sites. ${ }^{4}$ On most other land, no official permit is required and there is no restriction of fieldwork, beyond the landowner's consent.

In this third instalment of what I have termed the heritage hell series, ${ }^{5}$ I revisit the Austrian situation, and particularly $\S 11$ (1) of the Denkmalschutzgesetz [DMSG] 1923 (Austrian Heritage Protection Law), in the light of two recent and significant court findings on the matter of 'excavation' or 'research permits'. Austria serves as a case study to highlight wider issues, regarding the interpretation and application of heritage laws by state or national heritage agencies. Such issues though perhaps in less extreme form than in Austria - can and do exist in some other countries and highlight how (the) international authorised heritage discourse(s) $[\mathrm{AHD}]^{6}$ can severely influence the interpretation of heritage laws and the development of national or state heritage management policies and practices. 


\section{The Austrian situation: the official interpretation by the BDA}

I have provided a general summary of Austrian archaeological heritage protection law in a previous paper, ${ }^{7}$ and thus will not repeat this here. Rather, I will jump directly to the legal provision which (once again) particularly concerns me in this paper, namely $\S 11$ (1) DMSG, which regulates archaeological fieldwork in situ. Until recently the Austrian National Heritage Agency, the Bundesdenkmalamt [BDA], has maintained that any archaeological fieldwork in situ would require a permit according to $\S 11(1)$ issued by it to be legal. ${ }^{8}$ Most recently, it has restated this explicitly in its official Richtlinien für archäologische Maßnahmen (Guidelines for Archaeological Measures), ${ }^{9}$ which it attaches as a firm condition to any permit it grants:

"A precondition for the initiation of any excavations "and other research in situ for the purpose of finding and investigating moveable and immovable monuments" ( $\$ 11$ (1) DMSG) is the existence of a permitting decision of the BDA according to $\S 11$ (1) DMSG." ${ }^{10} .{ }^{11}$

The BDA has also consistently maintained that such a permit is required regardless of whether any archaeology is known or suspected to exist where the fieldwork is to be conducted; and that this requirement extends to any kind of archaeological fieldwork, regardless of its impact on the archaeological resource. Thus, in its official Guidelines, it lists non-invasive methods like the purely visual inspection of the landscape for surface features ${ }^{12}$ and geophysical surveys ${ }^{13}$ as requiring such a permit. It also, since $\S 11$ (1) explicitly states that such permits can only be issued to archaeology graduates, restricts them strictly to individuals who have completed a relevant academic degree.

This official interpretation of the provisions of $\S 11$ (1) DMSG by the National Heritage Agency firmly puts Austria into the 'German' model of managing fieldwork in situ. It is extremely restrictive in limiting fieldwork consent to archaeology graduates, and falling just short of claiming legal privilege for the BDA alone to conduct fieldwork. ${ }^{14}$

\section{Could the law be interpreted differently?}

I presented the official interpretation in my previous papers on $\S 11$ (1) DMSG in HEN $2 / 2,{ }^{15}$ hinting at my doubts over this interpretation in HEN $7 / 4,{ }^{16}$ and more forcefully elsewhere. ${ }^{17}$

Suffice to say Austrian law can be interpreted quite differently and my own interpretation of $\S 11$ (1) differs radically from that presented above; for several reasons.

If quoted in full, the relevant first sentence of $\S 11$ (1) DMSG reads:

"Research by changing the ground or the ground beneath water (excavation) and other research in situ with the purpose of finding and investigating moveable and immoveable monuments beneath the surface of the ground or water is only allowed with a permit by the National Heritage Agency, unless $\S 11$ (2) and (9) stipulate different conditions (research excavation)." (§ 11 (1) DMSG; emphasis: RK). ${ }^{18}$

My emphasis highlights my first disagreement with the official interpretation of this clause by the $\mathrm{BDA}^{19}$ : the law explicitly states that the purpose of the fieldwork must be to discover (or investigate) evidence located beneath the surface of the ground or water. Thus, it seems legally impossible that fieldwork to recover surface finds (field artefact collection) should be subject to this provision.

More significantly, though, the law uses the term monuments, that is, Denkmale, rather than using the more specific term used elsewhere in the DMSG for archaeology, Bodendenkmale. While this may seem like a very minor distinction, and indeed seemed sufficiently minor to the BDA that in its 
printed $2^{\text {nd }}, 3^{\text {rd }}$ and $4^{\text {th }}$ editions of its official Guidelines, it misquoted the law by replacing the former with the latter, ${ }^{20}$ it is highly significant. This is because the two terms are defined in the law quite differently. Bodendenkmale is defined as objects which "... could obviously be subject to the restrictions of this law" ( $\S 8$ (1) DMSG, emphasis: RK) $)^{21}$ whilst Denkmale is defined in the first sentence of the law, which also defines the limits of the applicability of the law itself:

"The provisions contained in this law are applicable to manmade, moveable or immovable objects (including their remains and traces of formative human adaptation as well as artificially created or shaped soil formations) of historical, artistic or other cultural significance ("monuments"), provided that due to this significance, their preservation is in the public interest." (§ 1 (1) DMSG, emphasis: RK). ${ }^{22}$

The provision of $\S 1(1)$, much like that of $\S 11(1)$, contains a condition restricting its applicability, and that of the law in general, to a specific subset of entities defined as 'monuments': those whose preservation is in the public interest. The definition of the term Bodendenkmale in $\S 8$ (1), on the other hand, is very wide and includes all objects which could be 'monuments'.

This is particularly significant since the DMSG, in $\S 1(2)$, determines what conditions must be met for the preservation of an object to be in the public interest; and in $\S 1$ (4) states that for public interest to become legally effective, it must be scheduled according to the procedures set out in $\S \S$ 2, 2a or 3. This implies that for the DMSG to be applicable, the object affected must be a scheduled monument. If that interpretation of the provisions of $\S 11(1)$ and $\S 1$ (1) in conjunction were correct, the management of fieldwork in situ would be entirely different from the BDA's interpretation.

Rather than applying to all fieldwork in situ, the requirement for consent by the BDA would be limited strictly to fieldwork in situ on scheduled monuments. ${ }^{23}$ Thus, Austria would fall into the "British" model, where fieldwork could be carried out anywhere outside scheduled areas, provided there was landowner consent.

My interpretation, rather than that of the BDA, is supported by the Austrian government's official explanatory report on the draft bill for the latest major revision of the DMSG (the Regierungsvorlage) in 1999. It stated that heritage management can only function effectively if restricted to a limited number of scheduled monuments. ${ }^{24}$

\section{Two court cases on the issue of research permits}

In 2017, the interpretation of $\S 11$ (1) and $\S 1$ (1) was tested in the courts. One case was brought by myself at the Bundesverwaltungsgericht ([BVwG] the Austrian Federal Administrative Court of Appeals), the other a case brought by the BDA against an Austrian citizen who conducted what it considered to be an illegal excavation, at the Verwaltungsgerichtshof ([VwGH]; Austrian Supreme Administrative Court). I will discuss them in that order, even though chronologically, the latter predates the former, a point I will return to later.

\section{Finding of the BVwG, dated 11.9.2017 [case no: W183 2168814-1/2E]}

The case I brought started with an ethical dilemma: I had been asked by the charity ArchaeoPublica to give a presentation about the requirements under Austrian law regarding fieldwork at a workshop for interested citizens on archaeological land surveying in Linz on 7-8 April 2017. During the preparation for this, I (once again) stumbled across the contradiction between the letter of the law and the Guidelines of the BDA ${ }^{25}$ noted above. This turned an otherwise academic matter into a real problem. I had to explain their rights and responsibilities under the law to members of the public; 
yet the BDA's interpretation of what those were differed considerably from my own. While that was easy enough to resolve - I simply explained both interpretations and advised the audience to stick with the BDA's to be safe - it was an uncomfortable position to be in. I thus decided that this matter needed to be resolved.

Having once again confirmed with the head of archaeology at the BDA that I had not misunderstood their Guidelines; ${ }^{26}$ I proceeded on 9 April 2017 to explain my legal opinion to him (and thus by proxy, the legal department of the BDA) in a strongly worded letter. This was accompanied by an application for a survey to collect surface finds in my parent's garden in Vienna, designed and explained explicitly as a test case. I also demanded they change their policy, practice, and Guidelines; since I believed they were acting without any legal basis in making $\S 11$ (1) DMSG-permits a requirement for surface surveys.

The latter is an important point: Austria is a democratic republic, based on the rule of law. As such, the principle that "All public administration must only be exercised according to the law" (Art. 18 (1) Bundes-Verfassungsgesetz [B-VG] ${ }^{27}$ is explicitly enshrined in its constitution. The BDA thus must not apply any policies or practices for which there is no legal basis: any administrative action without such a legal basis is necessarily unconstitutional and, as such, illegal. ${ }^{28}$

My demand that such changes should be made was not heeded. The BDA instead proceeded to a decision on my application despite the fact that I had explicitly stated in the accompanying letter I was only looking for surface finds, did not anticipate that I would discover any "moveable monuments" and that nothing of any significance had ever been found on that plot of land; not even during the construction of my parent's house - my childhood home - in the 1970s. I, therefore, expected that the BDA would decline my application as beyond its jurisdiction.

Nevertheless the BDA granted me the permit and, as always in such cases, attached numerous conditions, including that my survey would need to be conducted in compliance with its official Guidelines. ${ }^{29}$ It also made it conditional that I had to ensure that sufficient funding was available for the conservation of any finds made, their scholarly assessment, the preservation of any immoveable Bodendenkmale discovered and any restoration works required in situ. This is particularly remarkable, since even owners of actually scheduled monuments are only required by law to maintain their property in sound condition, for example by replacing broken windows or roofing slates. There is no legal basis to compel anyone to carry out (or fund) so-called active conservation measures, let alone restorations, anywhere in the DMSG. ${ }^{30}$

This gave me sufficient grounds to appeal the decision. My appeal was mainly based on the argument outlined above, even though I added a host of other arguments as to why it was illegal for the BDA to have granted me this permit. Also, in case the BVwG were to uphold the right of the BDA to grant this permit, I appealed against most of the conditions the BDA had attached to it.

On 11.9.2017, Judge Erika Pieler ${ }^{31}$ found in my favour, rejecting the need for my application as it lay outside the jurisdiction of the BDA. The judge gave three main reasons for her finding:

Firstly, $\S 11$ (1) DMSG explicitly states that a permit was required for research for monuments beneath the surface of the ground, and my application explicitly stated that I intended to only collect surface finds. Thus, the provisions of $\S 11$ (1) could not be applied to my application.

Secondly, there was a finding by the VwGH (dated 24.6.1985, case no: 84/12/0213) ${ }^{32}$ which had clearly established that the provisions of $\S 11$ (1) could not be applied to the collection of surface finds. While this had been found under an earlier version of the DMSG, it still was applicable, since 
the precise wording of $\S 11$ (1) did not include the condition beneath [etc.] at the time of this finding. Rather, this had only been added in 1990.

Thirdly, a recent finding by the $\mathrm{VwGH}$ (discussed below) had determined it was a necessary precondition for the applicability of $\S 11$ (1) that there was evidence that it was at least probable that monuments were present in situ and would be discovered during fieldwork. Yet, since I had stated in my application that I did not expect to discover monuments, and all available evidence indicated none whatsoever were present in situ, § 11 (1) was also inapplicable in this case.

The judge also found the case unfit for further appeal, since the law was clear, as was Supreme Court judicature, and thus there were no remaining questions justifying an appeal to the VwGH.

In effect, the Judge declared that there was no legal basis for applying $\S 11$ (1) to surveys intended to discover surface finds, and any issuing of permits for such activities by the BDA in violation of Art. $18 \mathrm{~B}-\mathrm{VG}$ and thus illegal.

\section{Finding of the VwGH, dated 23.2.2017 [case no: Ro 2016/09/0008]}

It is remarkable that Judge Pieler, in her finding, had had to remind the BDA of this recent finding by the VwGH, which had been issued less than two months before I had submitted my application. Its implications for managing fieldwork are huge and everyone in the BDA's law and archaeology departments should have been aware of its existence and the consequences for policy and practice.

The case which led to this judgement originated when the BDA reported a citizen to the prosecuting authority, the Bezirkshauptmannschaft Liezen (the local county council), for conducting an excavation without a permit according to $\S 11$ (1) DMSG. He had conducted fieldwork on a prehistoric copper mine dump by excavating a few small trenches some $50 \mathrm{~cm}$ deep, to extract samples for scientific analysis. The county council found his actions in violation of $\S 11$ (1) and fined him $€ 1,000$ for this administrative offence. Believing he had done nothing wrong, the offender appealed at the Landesverwaltungsgericht Steiermark (Styrian State Administrative Court of Appeals). He argued that the mine dump was not a monument according to $\S 1$ (1) DMSG, but rather a natural soil formation; and that, thus, the provisions of $\S 11$ (1) were inapplicable. The Styrian court found in his favour and quashed the fine; allowing a further appeal to the VwGH to the local council. In its finding on that second stage appeal, the VwGH found that the Styrian court had erroneously accepted the offender's argument that the mine dump was a natural soil formation. Thus, it referred the case back to the Styrian court, with the instruction that it would have to determine whether the specific mine dump in question is a monument to which the provisions of $\S$ 11 (1) can apply.

The county council in its appeal had also requested, as is possible under Austrian law, that the VwGH determine the circumstances that constitute the element for the purpose of finding and investigating of the offence, what criteria were to be used to determine whether it had been fulfilled, and when 'purposefulness' of such an action could be assumed. The VwGh heeded that request by extracting two legal rules (Rechtssätze) from its finding. In Austrian civil law, legal rules are similar to precedent in common law systems. Published separately from the finding, they determine how a particular aspect of the law is to be interpreted.

The first of them states that for $\S 11$ (1) DMSG to be applicable at all, the monument to be investigated must be already known or that it was the intention of the investigation to lead to the discovery of a monument. The second is much more interesting, since it specifies that it is not just the subjective intent of the researcher which determines whether $\S 11$ (1) applies. Rather, the objective criterion whether there is any specific evidence that monuments are present in situ 
beneath the surface must also be considered. Obviously, in case of investigation of a monument positively known to the researcher, foreknowledge would be a given. In case of the intended discovery of monuments, however, at least some evidence must support the probability of discovery. Examples of such evidence cited by the VwGH include publicly accessible expert testimonies, publicly accessible sources, or ongoing scheduling procedures. It concludes by stating that the significance of a monument is determined by its appreciation by the academic community and that it is a necessary precondition for the applicability of the DMSG that a monument is present or in case of $\S 11$ (1) that there is at least an expectation of finds.

While leaving somewhat more room for interpretation than the finding of the BVwG, it is still clear that this finding has important implications for managing fieldwork in situ. The BDA's jurisdiction in applying $\S 11(1)$ is restricted to fieldwork on sites that have generated some evidence that archaeological monuments will be found. If generously interpreting the VwGH's inclusion of "other publicly accessible sources", this could refer to published reports of stray finds, or surface features indicating the presence of archaeology. It would mean that, since the BDA is required by $\S 11$ (7) DMSG to publish an annual report of all relevant finds made in Austria, the Fundberichte aus Österreich [FÖ], fieldwork on any site reported in past issues of the FÖ could be subject to $\S 11$ (1). In absolute numbers, that would mean an estimated c.50,000 archaeological find spots in Austria; ${ }^{33}$ though more recently, Picker et al. have given a much lower figure of 19,550 sites known to the BDA. $^{34}$

However, that would still not change the finding by the VwGH which requires the BDA to radically change its policy, practice and guidance regarding the applicability of $\S 11$ (1) DMSG. After all, even if this interpretation were correct, it is certainly not 'any' fieldwork in situ which requires a permit by the BDA, despite the BDA maintaining this position for decades. ${ }^{35}$ Rather, it is only fieldwork on known or suspected archaeological sites which requires such a permit. Assuming that on average, each site known to the BDA covers an area of $c .1$ hectare, that would mean such a permit would only be required for fieldwork on c. $0.5 \%$ of the total Austrian landmass. Everywhere else, no $\S 11$ (1) permit can be required, and thus anyone may freely conduct fieldwork as they see fit, as long as they have landowner consent.

Thus, even in the 'best case' scenario, Austria would have to be considered to be nowhere near the 'German' model for managing fieldwork in situ, but rather closer to the 'British' model, even if somewhat less liberal. Yet, there are indeed a number of good reasons to believe that the finding of the VwGH has to be interpreted much more strictly.

First, the VwGH interprets the applicability of $\S 11$ (1) teleologically by unequivocally linking it to the definition of the aims and applicability of the DMSG in $\S 1$ (1). And, as already highlighted above, that limits its applicability to monuments whose preservation is in the public interest. But since that public interest only becomes legally effective by scheduling, this implies that none of the provisions of the DMSG, including those of $\S 11(1)$, can be applied to non-scheduled archaeological sites.

Second, $\S 37$ (6) DMSG stipulates that if during an ongoing prosecution or court case the BDA decides that there is no or has never been a public interest in the preservation of the affected monument the case must be dropped. This also applies to criminal damage proceedings according to $\S 126$ (1.3) Strafgesetzbuch (Austrian Penal Code). While commentaries suggest that this is misguided legal policy, ${ }^{36}$ it is an inevitable consequence assuming the legislator intended the applicability of the DMSG to be strictly limited to monuments whose preservation is in the public interest. And that is exceedingly likely, since it indeed explicitly stated exactly this in $\S 1$ (1). 
Third, and perhaps most importantly, the DMSG also contains a provision creating the potential to schedule monuments whose significance cannot yet be conclusively determined. In $\S 1$ (5), it states that if a monument has not been sufficiently researched, as in case of as yet unexcavated archaeology, it can still be scheduled if the current state of research indicates it is at least probable that it fulfils the legal criteria for scheduling. Thus a lower than normal standard of evidence is permissible for scheduling, specifically for unexcavated archaeological monuments.

This provision was first introduced in the 1990 revision of the DMSG (then numbered $\S 1(2)),{ }^{37}$ specifically with the aim to satisfy Austria's legal obligation under Art. 2 (b) of the London Convention, "to create reserve zones for the preservation of material evidence to be excavated by later generations of archaeologists".$^{38}$ In the government's explanatory report to the bill for the 1990 revision, these reserve zones are referred to as "Fundhoffnungsgebiete", ${ }^{39}$ which, as literally as possible, translates into English as 'find expectation areas'.

Yet, the finding of the VwGH makes an 'expectation of finds' a precondition for the applicability of $\S$ 11 (1) and lists as examples of the kind of evidence required to create such an expectation exactly those which would be required for scheduling, like expert testimonies. It thus follows that, if such an expectation must exist for $\S 11$ (1) to be triggered, the site on which fieldwork is to be conducted must be such a find expectation area. Yet, the legislator has foreseen the need to protect such find expectation areas by law and regulated the situation through $\S 1(5)$, allowing sites to be scheduled with a lower than normal standard of evidence. This again implies that a site must be scheduled for the provisions of $\S 11$ (1) to apply; or at least be in the process of being scheduled, the second example the VwGH lists as sufficient evidential support to create the necessary 'expectation of finds'.

This makes it exceedingly unlikely that this finding can be interpreted to arrive at the 'best case' scenario. Instead, the more likely interpretation means the 'worst case' for the BDA, with $\S 11$ (1) applicable exclusively to land either containing scheduled monuments; in the process of being scheduled; or, at the very least, where publicly available expert testimony indicates the probability that significant finds will be discovered. This effectively restricts the applicability of $\S 11$ (1) to fieldwork on scheduled monuments and World Heritage sites, since these currently are the only ones in Austria for which expert testimony determining their significance exists. In absolute numbers, this would be at least $c .1,100$, and perhaps up to as many as $c .1,500$, archaeological sites. In comparison to England, which has about 1.5 times the landmass of Austria, where c.17,500 archaeological monuments are scheduled, ${ }^{40}$ the numbers are woefully low.

Arguably, the finding does not de jure restrict the applicability of $\S 11$ (1) to scheduled monuments only: it does leave the possibility of publishing expert testimony indicating that a non-scheduled site does meet the legal criteria for scheduling. This would apply even if the site was not yet in the process of being scheduled. Thus, in the future, more sites could be brought within the jurisdiction of $\S 11$ (1) DMSG than there are scheduled sites. Although this does not necessarily resolve the Austrian situation it does bring it much closer to the 'British' model.

\section{The consequences of the two findings}

The main consequence of the first case is that the BDA will no longer subject surface surveys to $\S 11$ (1) DMSG. I have been provided with a copy of an internal email informing staff of the BDA's archaeology department to immediately desist from issuing any further $\S 11$ (1) permits for applications for surveys which meet this condition. The same e-mail also indicates that the BDA's official Guidelines ${ }^{41}$ will be changed in due course and I have been assured that this change in policy 
and practice will be appropriately communicated to both the archaeological community and the Austrian public.

That said, while this is clearly a significant change in policy, its actual effects in practice will be limited. While I know that $\S 11$ (1) permits have indeed been occasionally issued for surface surveys; it is evident (also from the FÖ) that this happens very rarely. Its main effect in practice will be on community archaeologists, who want to conduct surface surveys, and who may now do so freely without fear of prosecution. While this will benefit the woeful state of the land survey in Austria, ${ }^{42}$ whether it will significantly improve it is questionable. After all, cases against such community archaeologists were rarely brought by the BDA in the past, and thus the deterrent effect of this is unlikely to have been significant.

The second case, however, should have much more significant consequences, not just on policy, but also on practice. Nevertheless, it is concerning that the BDA seems to have taken no steps so far to implement the findings of the $\mathrm{VwGH}$. This is proven beyond any reasonable doubt by the first case: since the findings in the second predate the application which led to the first, the need to bring the first should never have arisen. Had the BDA implemented the findings of the $\mathrm{VwGH}$, it would have had to decline my application due to its evident lack of jurisdiction. That it did not, despite the clarity of the legal situation, implies that something is amiss. At the very least, it inspires little confidence in the BDA's capability to lawfully dispense its duties. This is particularly important in light of recent criticism of the BDA's (lack of) competence regarding the dispensation of its legal duties by the Austrian Court of Audit (Rechnungshof). ${ }^{43}$

At any rate, even in the 'best case', the BDA will have to change its policy and practice significantly. After all, the provisions of $\S 11$ (1) are certainly inapplicable to fieldwork on c. 99\% of the Austrian landmass ${ }^{44}$ where no archaeology is known or suspected to exist. This would have only limited impact on professional archaeological fieldwork. Compliance with the BDA's Guidelines only becomes compulsory when subject to the permit. However, since most of professional archaeological fieldwork happens on already known sites, in the 'best case' scenario, a permit would remain compulsory for most. Presumably, it thus would only be a small percentage - perhaps up to $25 \%$ - of the $c .500$ excavations and surveys permitted annually by the BDA in recent years ${ }^{45}$ which would no longer require a permit.

However, the impact on non-professional metal detecting and, potentially, the future of archaeological land survey in Austria, may well be considerable. Metal detectorists can and will rejoice, since permit free fieldwork by anyone is now clearly legal in a large part of Austria. While this is unlikely to have a discernible effect on the incidence of metal detecting in Austria, it well may encourage at least some metal detectorists to start reporting their finds to the BDA again. ${ }^{46}$ Whilst resentments built up over at least the past three decades will need to calm, this may, in the long run, lead to a significant improvement of the archaeological land survey of Austria. ${ }^{47}$ This could be even more significant if supported by something similar to the Portable Antiquities Scheme [PAS] ${ }^{48}$

In the 'worst case', however, the consequences would be dramatic, especially for professional fieldwork. Most professional fieldwork is conducted on already known or suspected, but not scheduled archaeological sites. Thus, in the worst case, most professional archaeological fieldwork will not need a $\S 11$ (1) permit; and consequently would not be bound to comply with the Guidelines. ${ }^{49}$ Given that compliance with the Guidelines costs considerable amounts of money, it is likely that many private Austrian archaeological contractors will not comply, if only to cut costs in a competitive market. The worst case would mean that, in effect, quality assurance by the BDA of professional archaeological fieldwork in Austria would cease. 
A further implication is that of the $c .10,000 \S 11$ (1) DMSG permits granted by the BDA in recent decades, almost all will have been issued illegally. Thus, all conditions attached to them, including the often costly compliance with the Guidelines ${ }^{50}$ and other permit conditions, will also have been illegal. If lawsuits for damages ensue as a consequence of this, it could adversely affect the professional relationships in Austrian archaeology and trust in the BDA and its officials.

Where metal detecting is concerned the difference is that even more of the Austrian landmass than under the 'best case' scenario would be available to detectorists for detecting without the need for a $\S 11$ (1) permit. How much that would change detecting patterns, and thus reduce the possible benefits for the archaeological land survey of Austria, is debatable.

These are serious implications for archaeological heritage management in Austria. What was presented as a highly restrictive legal system in its official interpretation by the BDA turned out to be quite liberal. Whether the changes set out above will be to the benefit or disadvantage of Austrian archaeology remains to be seen.

\section{How did it come to this?}

First, few archaeologists in Austria appear to know what the law on archaeological heritage protection actually says or how to correctly interpret it. This problem starts during study for an archaeology degree, where heritage legislation and how to interpret it in its wider legal framework is not taught anywhere near sufficiently much or well. This is evident from the archaeology curricula at Austrian Universities which regularly include heritage law and policy either only as minimal elements of teaching, optional modules, or not at all. If taught formally at all, it sometimes is taught by archaeologists who have little interest in and understanding of it. Even if - as sometimes happens it is taught by an archaeologist working for a heritage agency, teaching will focus mostly on current policy and practice, not the law or difficulties with its interpretation and application. ${ }^{51}$ This impression of insufficient quantity and quality is shared in an open letter by the Association of Archaeology Student Unions [DASV ${ }^{52}$ ], circulated in 2016, in which it reiterated its demand (first made in 2012) that University teaching of archaeological heritage management and protection should urgently be improved..$^{53}$

Second, this situation seems to remain unchanged in Austria where throughout our careers we mostly learn formally and informally about heritage law from other archaeologists. This is evident from conferences and publications in which aspects of heritage law and policy are discussed: jurists specialised in heritage law, or indeed any jurists, hardly ever contribute to these. ${ }^{54}$ Discussions of heritage legislation or relevant court cases are presented by archaeologists in exceptionally short, descriptive pieces in archaeological journals ${ }^{55}$ or academic articles written based on interviewing BDA archaeologists. ${ }^{56}$ Even in advisory introductions - again written by archaeologists - for volunteers running local museums, ${ }^{57}$ there is no reference to specific provisions of the law, let alone to secondary literature like the legal commentary on the law. ${ }^{58}$ In some cases, the law has been misrepresented in such articles. For instance, in her short summary of changes to law and practice following the 1999 revision of the DMSG, the then Head of the Department of Archaeology in the BDA states explicitly that the systematic survey of freshly ploughed fields (for surface finds) is subject to the permit requirement of $\S 11(1) . .^{59}$

In some cases, the need for critical reflection on the underlying values and principles of archaeological heritage management (and thus also heritage law and policy) is deemed unnecessary because of the AHD: "The lack of a theoretical debate on the fundamentals of archaeological heritage management is due to the existence of a general consensus between all involved experts for 
approximately two centuries". ${ }^{60}$ Throughout our training and careers, the values underlying the archaeological ethos and those prominently expressed in the AHD ${ }^{61}$ - the 'consensus' referred to by Pollak ${ }^{62}$ - dominate. They affect how we perceive not just our role and construct our professional identity, but also how we perceive the laws directly pertaining to 'us'. Thus, concepts like the archaeologist as a guardian or steward of the past for the future, ${ }^{63}$ or as an advocate for archaeology and its protection, ${ }^{64}$ as well as the need for technical competence in its care, particularly in fieldwork, and the need for permission from a public authority, ${ }^{65}$ are inculcated in students and reinforced in professional debates throughout our careers.

Third, these values and concepts are further reinforced by the archaeological provisions of heritage law(s) themselves. After all, their archaeological content has mostly been devised by archaeologists, rather than by jurists or politicians. ${ }^{66}$ Thus, the values expressed and the principles included are once more those of the AHD, even if somewhat watered down by lobbying from other interests. Analysis of the laws and their provisions, often simplistic and superficial, actively supports this (even in legal commentaries written by heritage jurists) ${ }^{67}$. A monument protection law - as Denkmalschutzgesetz literally translates into English - is supposed to protect monuments and a legal prohibition against unpermitted fieldwork as in $\S 11$ (1) DMSG must mean fieldwork must not be conducted without a permit, even if it is obvious from sub-clauses to the provision that this is not what the legislature intended.

Fourth, archaeological ethics, at least in the germanophone countries, is a disciplinary rather than a professional ethic. ${ }^{68}$ Grossly oversimplified, the difference between these two kinds of ethics is that the former has the discovery of 'the $\operatorname{truth}^{\prime 69}$ by the academic, while the latter posits the societal benefit of the work of the professional as its main raison d'être. ${ }^{70}$ If discovery of 'the truth' is the main goal, it is essential that that the sources and processes of discovery are protected and their quality controlled. Yet it matters not whether anyone benefits; the discovery of the truth is sufficient of and in itself. Thus, in archaeological disciplinary ethics the only goods that are assigned a high value are those related to the preservation of sources. Consequently, archaeologists assign high values to the preservation and study of archaeology, often the highest values, in their personal ethics, rather than its benefits for other humans and society, and in ethical dilemmas involving archaeology these archaeological values will often prevail.

Fifth, because of our academic training as archaeologists, we tend to believe that we know what is 'right' where archaeology is concerned. ${ }^{71}$ This becomes apparent in debates about civil rights and more generally the rights of 'the public' to make decisions concerning archaeology. These rights, despite being guaranteed in both constitutional and international law, ${ }^{72}$ are often seen by archaeologists as secondary concerns compared to archaeological quality assurance; especially in the context of the non-professional extraction of archaeology ex situ ${ }^{73}$.

Sixth, and connected to this, we also intensely feel archaeology is threatened. The whole conservation ethos, our heritage laws, our disciplinary values and needs, and self-perception and identity as guardians of the past, are all based on the feeling that 'our heritage' needs to be protected. Most of these threats we see as resulting from human activity in what could be called the 'long present', ${ }^{74}$ by 'them': the construction industry, landowners, antiquities traders, and the selfserving looters, who all physically threaten its preservation; ${ }^{75}$ but also the politicians, the lawyers and the lobbyists, whose influence and decisions may well threaten the framework in which we operate and the instruments which enable us to fulfil our 'duty' to protect archaeology. Since we are the expert guardians, who know what is best for 'our heritage', defined as a 'common good' both by the AHD and our laws, we feel morally justified to defend it against 'them'. In that process, we see the law as a crucial instrument. Friedrich Lüth, for instance, when he was still Landesarchäologe 
(state archaeologist) for Mecklenburg-Vorpommern, that is an agent of the state, expressed this quite explicitly when declaring that the state had to protect archaeology "...by means of the law in the interest of all ... from the grasp of all...". ${ }^{76}$

Seventh, most archaeologists are concerned not with the detail of the law but with what they consider both legitimate and just. ${ }^{77}$ We are concerned with heritage law mainly because (1) it is the law that pertains most directly to our primary interest, and (2) because it can be used for our purposes. We tend to see it as a means to an end, and value it only inasmuch as it allows us to achieve the ends we desire. This leads to regularly expressed demands for laws perceived to be ineffective to be made stricter, and to be more effectively policed; even where we already overinterpret their applicability considerably. ${ }^{78}$

In Austria, the factors have created a situation in which archaeologists may not know what the law actually says, often do not fully understand it, do not realise its limitations, or appreciate it as society's principal means of ensuring an equitable reconciliation between different interests. Instead it is seen primarily as a means to achieve an end. What that end should be is determined by our values and interests, which lead us to believe that we know what is best for archaeology; that it is threatened by the actions of others; that we have been assigned the duty by society to protect it against these threats; and that, for these reasons, we are entitled to decide the fate of this 'common good' in the interest of everyone, if necessary against the interests of anyone. In other words, we believe our cause is just.

Consequently, if we believe our cause is just, but the aims we try to achieve conflict with the law, it is tempting to believe the law is wrong. ${ }^{79}$ Thus, whether consciously or subconsciously, we search for ways to make the wrong law right. Ideally, this should be done by changing the law, and that's often what we (try) to do if we can. But if we cannot, we sometimes feel forced to find another way to make it right. For instance, we start reading the law ever more selectively; or indeed start to stretch our interpretation of it. In effect, if the law does not quite fit with our expectations, and cannot be changed, we simply make it fit through administrative practice.

This process is evident in how the BDA has interpreted the DMSG, and particularly $\S 11$ (1), over the last few decades. I have explained how and why the provisions of $\S 11$ (1) were changed in its 1990 revision because a metal detectorist got away at the Supreme Court with extracting eight Roman coins ex situ by claiming that he had merely collected them as surface finds. ${ }^{80}$ Thus, we changed this archaeologically unfit provision, which stated that a permit was required just for "excavations", and added to it the clause "and any other research in situ". Unfortunately, this rephrasing was spotted, quite possibly by some jurist concerned that this could extend its applicability to any attempt to find anything, who restricted its applicability again by adding "beneath the surface of the ground or water", thwarting our efforts.

Thus, an alternative was sought. The BDA started, ever so slightly, to misread the letter of the law by reading into $\S 11$ (1) the very wide term Bodendenkmale, defined in $\S 8$ (1) as any object which "could be subject to the restrictions of this law", where the law actually uses the much narrower term Denkmale, defined in $\S 1$ (1) as significant objects whose preservation is in the public interest. This, with one fell swoop, appeared to bring all metal detecting under the prohibition of $\S 11$ (1) against unpermitted fieldwork. Clearly that was already, as the finding of the VwGH discussed above proves beyond any reasonable doubt, a significant misinterpretation of the law.

Then, mission creep set in. I cannot say precisely when the BDA started to try to bring plain surface surveys under the provisions of $\S 11$ (1), nor the reasons why it did so. It may well be that some 
metal detectorist, whose lawyer had found the $1985 \mathrm{VwGH}$ finding, won a case in the 2nd level of jurisdiction, the findings of which are not normally published, by claiming that he had only collected surface finds. Or it may be that the BDA simply started to do so because some of its officials believed that it was what the law said, due to the misreading of its letter discussed in the previous paragraph, or at least believed that that was what it should say. ${ }^{81} \mathrm{It}$ is unlikely that the BDA applied the law this way consistently by 2008 , because in that year, it still published a lengthy report by an amateur archaeologist about his surface surveys in Lower Austria in the FÖ, ${ }^{82}$ without reporting him to the prosecuting authority for allegedly violating $\S 11$ (1). But at the latest by 2012 , it did list surface surveys as research requiring a $\S 11$ (1) permit in its $2^{\text {nd }}$ edition of its Guidelines.$^{83}$ Of course, this was even more obviously illegal, as the BVwG finding discussed above conclusively proves. Yet no one complained (successfully) until I did.

\section{Quis custodiet ipsos custodes?}

Which brings me to my final point. The BDA has maintained its position for at least 26 years because there is no internal or external oversight. There are the courts, and appeals are possible through several levels of jurisdiction, as the findings of the BVwG and VwGH discussed in this paper demonstrate. However, as the evidence above suggests, decisions are rarely appealed, except in relation to scheduling. Judicial oversight in practice, therefore, is limited. Where the provisions of $\S$ 11 (1) DMSG are concerned, there are only three court judgements in over 30 years: that of the BVwG in the case I brought myself, the VwGH finding discussed above, and the finding of the VwGH dated 24.6.1985, case no: 84/12/0213.

Importantly, although the Austrian Court of Audit has heavily criticised the BDA for various managerial issues, ${ }^{84}$ archaeologists outside the BDA are reluctant to challenge the official body. Instead, the community mostly seems to act as an echo chamber, confirming to the archaeologists in the BDA that their interpretation of the law is acceptable. Despite complaints by archaeologists in the past regarding the granting of excavation permits and the conditions attached to them, to the best of my knowledge, none have been challenged in the courts.

Lastly, ordinary citizens, hobby archaeologists, and metal detectorists, mostly simply ignore the BDA. The risk of prosecution and a fine of $c$. $€ 500$ is minimal, and the need for expensive legal advice for appeals sufficient to put off all but the most determined from challenging the BDA, even if they are caught and fined. Thus, the BDA remains largely unchallenged.

\section{Beyond Austria}

The situation outlined above, that heritage agencies sometimes considerably overstep the bounds of their legal authority, is not limited to Austria alone.

The German state of Hesse, in its Denkmalschutzgesetz [HDSchG], also has a provision which states "Research, especially excavation, with the aim of discovering Bodendenkmäler, requires permission by the Technical Authority for Monuments" (§ 22 HDSch 2016; previously $\S 21$ HDSchG 2012). ${ }^{85}$ The Denkmalfachbehörde (Technical Authority for Monuments) is the Landesamt für Denkmalpflege Hessen [LfDH], specifically its department for archaeology, the hessenARCHÄOLOGIE. Like the Austrian BDA, it attaches Guidelines ${ }^{86}$ to any fieldwork permits and compliance with them is a legally binding obligation.

When I examined them closely in 2016, the Guidelines on the Landesamt für Denkmalpflege Hessen website included a rather surprising statement in chapter "I. Area of applicability of the Guidelines": "For excavations in the land of Hesse, which are based on a research permit according to $\S 21$ 
HDSchG or a monument law permission according to $\S 16$ HDSchG, the rights to analyse the finds and publication rights lie with the Landesamt für Denkmalpflege Hessen." (emphasis: RK). ${ }^{87}$

This is important for two reasons: (1) all archaeological excavations conducted in Hesse by parties other than the LfDH (which according to the commentary to, but not the letter of, the HDSchG is exempt) ${ }^{88}$ require such a permit; and (2) all publication rights according to $\S 12$ (1) German Urheberrechtsgesetz ([UrHG], Intellectual Property Rights Law) are property of the author of the original work of art or science. The UrHG applies also to written and photographic works as well as illustrations of scientific or technical nature such as drawings, plans, maps, sketches, tables as defined in its $\S 2$ (1). According to its $\S 15(1-2)$, their author has the exclusive (but transferrable according to its $\S 31$ ) right to publish them. Thus, this appears to be a dispossession of archaeologists of their intellectual property by the state of Hesse.

Art. 14 (3) Grundgesetz [GG], the constitutional law of the Federal Republic of Germany, while allowing for the dispossession of property of individuals by the state for the public good, requires any such dispossession to be based on a law which determines fair compensation. While this may be included in the HDSchG 2016 the form of $\S \S 26$ (1.2) and 27 (§§ 25 (1.2) and 26 HDSchG 2012 respectively), neither $\S \S$ were quoted in the Guidelines. ${ }^{89}$ Nor were these $\S \S$ cited in copies of permits I have seen, which included an identical statement to the one quoted above as a separately itemised condition..$^{90}$ Moreover, there also was no indication that the legal owners of any IP (according to $\S 2$ (1) UrHG) created during any permitted fieldwork in Hesse were actually compensated according to the provisions of the HDSchG, or that compensation had ever been discussed with any of them.

This condition in fieldwork permits by the LfDH thus appears to have been contrary to the law. In permits applied between $1 / 8 / 2015$ and $12 / 1 / 2017$, the LfDH appears to have dispossessed professional archaeologists of their intellectual property without paying them the legally required fair compensation. ${ }^{91}$

To address this problem, I wrote a strongly worded letter to the state archaeologist for Hesse, arguing in detail why I considered this to be illegal, and demanded that policy and practice be changed. Subsequently the LfDH fulfilled my demand and changed its Guidelines immediately, backdating them to $1 / 1 / 2017$, though published online only on $17 / 1 / 2017 .{ }^{92}$

This is relevant in the context of this paper as colleagues working in Hesse were concerned at the appropriation of publication rights by the LfDH. Much like my Austrian colleagues, few complained, formally; and like in Austria, effective internal or external oversight of the LfDH appears to be lacking. Despite a clear legal framework it is clear that some heritage agencies may misinterpret the law to their own advantage.

\section{Conclusions}

This paper has shown that heritage agencies in Austria and Hesse do not always correctly apply the heritage laws they are supposed to execute. In both Austria and Hesse, it is not just administrative mistakes that lead to the law being incorrectly applied. Rather, it is in and due to heritage management practice that misapplication of the law can be systematic, wide-ranging, and affect almost every decision (at least in particular matters) an agency has issued over the course of years, if not several decades.

In Austria, interpretation of the Austrian Administrative Supreme Court finding discussed above (VwGH on 23.2.2017, case no: Ro 2016/09/0008) means that over the past c. 30 years, many 
fieldwork permits were issued by the BDA to professional archaeologists illegally. This may have financial consequences and have damaged the reputation of the heritage management sector in Austria.

It may also mean that despite the BDA's position, the law requires fieldwork permits only on scheduled sites, similar to the 'British' model. The implication is that the Austrian legal situation does not correspond to the 'German' model of subjecting all fieldwork to a state permit requirement. Rather, the fieldwork permit requirement of $\S 11$ (1) DMSG extends, at most, to land where there already exists evidence that significant archaeology is probably present.

The findings of the Austrian Federal Administrative Court of Appeals (BVwG on 11.9.2017, case no: W183 2168814-1/2E) also indicate that the BDA has misapplied the law. The ramifications are significant for professional archaeology in Austria and for the Austrian public. The problems regarding the consequences of $\S 11$ (1) DMSG related to finds reporting and the possibility of an archaeological land survey of Austria ${ }^{93}$ were not problems caused by the law itself but through the BDA's misinterpretation and misapplication of the law. The poor state of both finds reporting by members of the public and the archaeological land survey of Austria are a direct consequence of the heritage management policies and practices of the BDA. The problem resulting from this is that metal detectorists always had leave to engage in their hobby almost anywhere in Austria, because in most places, their activity is not prohibited at all. This could potentially be turned, at least somewhat, to the benefit of archaeology and the archaeological land survey of Austria, but only if it accompanied by introducing a system comparable to the UK's Portable Antiquities Scheme, which as of yet is lacking in Austria.

In Hesse the appropriation of publication rights to fieldwork records produced by third party professional archaeologists by the LfDH served to show that the issue of heritage agencies misinterpreting the law is not just an Austrian problem. In previous papers ${ }^{94}$ I have warned that archaeologists might be over-interpreting and over-extending the applicability of 'our' heritage laws, and be significantly overstepping the bounds of their authority. As the cases discussed in this paper demonstrate, this is now an established fact. In practice, such misinterpretation is due to a potent mix of limited knowledge, poor understanding and appreciation of the law and a bias characteristic of the authorised heritage discourse.$^{95}$ This can lead to misapplication of the law in administrative practice, exacerbated by the lack of judicial challenge and ineffective governance, whether within government agencies or by the discipline of archaeology as a whole.

\section{Lessons to be learned}

The situation in Austria and Hesse which I have detailed is a strong reminder that it is only once issues have been identified that legal remedies to deal with them can be formulated. We can learn from this that in some cases, we may have to try to change the law. In others, we may have approach problems somewhat differently than before. For instance, in Hesse, it might be possible to use the provisions of $\S \S 26(1.2)$ and 27 HDSchG 2016 to legally dispossess, provided fair compensation is paid, the original owners of IPR in fieldwork records of their publication rights, if that be deemed necessary. In yet other cases, we may have to accept that what we want is not achievable within the bounds of the law; and will have to find voluntary solutions for minimizing the damage and maximising any potential benefits of legally permitted activities for the archaeology. This is what England and Wales have done with the PAS; and the BDA in Austria may have to do the same, or try to assure the quality of fieldwork freely permitted by law by training as many members of the public as are interested in professional archaeological excavation and recording. 
The most important lessons to be learned from this paper, however, is that we must not try to achieve our aims by simply disregarding the law. Rather, we have to find legal ways to achieve them. Whether we like it or not: like everyone else, we also have to obey the law, since this is necessary if we do not want to have final judgement in the courts go against us.

\section{Bibliography}

Bazil, C., R. Binder-Krieglstein, and N. Kraft. Das österreichische Denkmalschutzrecht. Wien: Manz, 2004.

Bazil, C., R. Binder-Krieglstein, and N. Kraft. Das österreichische Denkmalschutzrecht. 2nd ed., Wien: Manz, 2015.

BDA. Richtlinien für archäologische Maßnahmen. 2. Fassung - 1. Jänner 2012. Wien: Bundesdenkmalamt, 2012.

BDA. Richtlinien für archäologische Maßnahmen. 4. Fassung - 1. Jänner 2016. Wien: Bundesdenkmalamt 2016. Accessed 19 September 2017, https://bda.gv.at/fileadmin/Medien/bda.gv.at/SERVICE RECHT DOWNLOAD/Richtlinien fuer archa eologische Massnahmen 4.Fassung.pdf.

Belford, P., and G. Wait. Adding value: an independent system of accreditation for archaeology and cultural heritage. Archäologische Informationen 41 (2018), forthcoming.

CIfA. Code of Conduct. Reading: Chartered Institute for Archaeologists, 2014. Accessed 10 September 2017, https://www.archaeologists.net/sites/default/files/CodesofConduct.pdf.

CoE. European Convention on the Protection of the Archaeological Heritage. London: Council of Europe, 1969. Accessed 22 September 2017, http://www.worldlii.org/int/other/COETS/1969/1.html.

CoE. European Convention on the Protection of the Archaeological Heritage (revised). Valletta: Council of Europe, 1992. Accessed 22 September 2017, http://www.coe.int/en/web/conventions/full-list/-/conventions/rms/090000168007bd25.

Davydov, D. „Jeder kann graben"? - Archäologisches Erbe im Spannungsfeld zwischen Partizipation und Gefahrenabwehr. Early View 22.8.2017, accessed 17 March 2018, https://lfd.hessen.de/sites/lfd.hessen.de/files/content-downloads/Davydov Spannungsfeld EV.pdf.

Farka, C. Neufassung des Denkmalschutzgesetzes 1999. Archäologie Österreichs 11/1 (2000): 78-79.

Farka, C. Die Abteilung für Bodendenkmale des Bundesdenkmalamtes. Jahresbericht 2008. Fundberichte aus Österreich 47. Wien: Bundesdenkmalamt, 2008: 9-96.

Fuchs, M. Der latènezeitliche Waffenfund vom Förker Laas Riegel, Bezirk Villach, Kärnten. Archäologie Österreichs 2/2 (1991): 19-24.

Fuchs, M. Der laténezeitliche Waffenfund vom Förker Laas Riegel. Die ersten Gerichtsurteile. Archäologie Österreichs 3/1 (1992): 72.

Hebert, B. (ed.). "Graue Schafe« - zur fachlichen Relevanz unautorisiert geborgener (Prospektions-) Funde. Fundberichte aus Österreich 50, Wien: Bundesdenkmalamt, 2011: 139-164.

Hebert, B. (ed.). Theorienbildung in der archäologischen Denkmalpflege. Beiträge des ExpertInnengesprächs vom 24. August 2010 in Schloss Thinnfeld. Österreichische Zeitschrift für Kunst und Denkmalpflege LXV/3 (2011): 207-287. 
Hebert, B. (ed.). Denkmalwerte und Denkmalschutz in der Archäologie. Ausgewählte Beiträge des Fachgesprächs vom 29. August 2013 in der Kartause Mauerbach. Österreichische Zeitschrift für Kunst und Denkmalpflege LXVIII/3-4 (2014): 293-343.

Hebert, B., and N. Hofer. Archäologie im Bundesdenkmalamt 2014. Fundberichte aus Österreich 53. Wien: Bundesdenkmalamt, 2011: 11-39.

Helfgott, N. Die Rechtsvorschriften für den Denkmalschutz. Wien: Manzsche Verlangs- und Universitätsbuchhandlung, 1979.

Karl, R. On the highway to hell. Thoughts on the unintended consequences of $\S 11$ (1) Austrian Denkmalschutzgesetz. The Historic Environment - Policy and Practice 2/2 (2011): 111-133.

Karl, R. Ein mikrolithischer Monumentalbau: Zur legalen Ein- und illegalen (?) Ausgrabung eines Weihnachtsmanns. NGÖ Jahresschrift (2014): 8-13.

Karl, R. More tales from heritage hell. Law, policy and practice of archaeological heritage protection in Austria. The Historic Environment - Policy and Practice 7/4 (2016): 283-300.

Karl, R. Obrigkeit und Untertan im denkmalpflegerischen Diskurs. Standesdenken als Barriere für eine Citizen Science? Forum Kritische Archäologie 5 (2016): 1-15.

Karl, R. Archaeological responses to 5 decades of metal detecting in Austria. Open Archaeology 2/1 (2016): 278-289.

Karl, R. The Freedom of Archaeological Research: Archaeological Heritage Protection and Civil Rights in Austria (and Beyond). Public Archaeology 16/1 (2017): 1-17.

Karl, R. Ich bin Hobbychirurg und Hobbypolizist. Archäologische Informationen 40 (2017): 73-86.

Karl, R. Warum es einer archäologischen Berufsethik nicht nur um den Schutz von archäologischen Quellen gehen kann. Oder, frei nach Mortimer Wheeler: The archaeologist is digging, not for things, but for people! Archäologische Informationen 41 (2018), forthcoming.

Leskovar, J. and S. Traxler. Archäologie in Oberösterreich - Herausforderungen und Perspektiven für Museen. In (Heimat-) Museen neu denken! 9. Oberösterreichischer Museumstag. Mondsee, 2010. Berichtsband, edited by Verbund OÖ Museen, 58-68. Leonding: Verbund OÖ Museen (2010).

LfDH. Richtlinien zur Grabungsdokumentation Archäologie und Behandlung von Grabungsfunden und Proben. Stand 1.8.2015. Wiesbaden: Landesamt für Denkmalpflege Hessen, 2015.

LfDH. Richtlinien zur Grabungsdokumentation Archäologie und Behandlung von Grabungsfunden und Proben. Stand 1.1.2017. Wiesbaden: Landesamt für Denkmalpflege Hessen, 2017.

LfDH. Richtlinien Archäologie. Stand 1.8.2017. Wiesbaden: Landesamt für Denkmalpflege Hessen, 2017. Accessed 23 September 2017, https://lfd.hessen.de/sites/lfd.hessen.de/files/contentdownloads/2017-8 GrabRichtlinie\%20Arch.pdf.

Lüth, F. Einführung in das Thema. Archäologisches Nachrichtenblatt 11/2 (2006): 102-106.

Picker, A., B. Hebert, R. Ployer, and M. Pollak. Braucht Österreich ein Unterschutzstellungsprogramm für seine archäologischen Denkmale? In Akten des 15. Österreichischen Archäologentages in Innsbruck, 27.Februar-1. März 2014., edited by G. Grabherr and B. Kainrath, 285-288. Innsbruck: University Press, 2016. 
Pollak, M. Zur Theorienbildung in der archäologischen Denkmalpflege in Österreich. Österreichische Zeitschrift für Kunst und Denkmalpflege LXV/3 (2011), 227-239.

Rączkowski, W. The "German School of Archaeology" in its Central European Context. In A History of Central European Archaeology. Theory, Methods and Politics, edited by A. Gramsch and U. Sommer, 198-210. Budapest: Archaeolingua, 2011.

Schofield, J., J. Carman, and P. Belford. Archaeological Practice in Great Britain. New York: Springer, 2011.

Schwammenhöfer, H. Ur- und frühgeschichtliche Fundstellen an der Nordseite der Donau. Fundberichte aus Österreich 47. Wien: Bundesdenkmalamt, 2008: 655-658.

Smith, L.. Uses of Heritage. London: Routledge, 2006.

Strobl, H., and H. Sieche. Denkmalschutzgesetz für Baden-Württemberg: Kommentar und Vorschriftensammlung. Stuttgart: Kohlhammer, 2010.

Szemethy, H.D. Zur Situation der, illegalen Archäologie' in Österreich. In Illegale Archäologie? , edited by W.-D. Heilmeyer and J.C., Eule, 157-164. Berlin: Weißensee Verlag, 2004.

Tyler, T.R. Why People Obey the Law. Princeton: University Press, 2006.

RH. Bericht des Rechnungshofes: Bundesdenkmalamt. Reihe Bund 2017/23, Wien: Rechnungshof, 2017. Accessed 28 June 2017, http://www.rechnungshof.gv.at/fileadmin/downloads/ jahre/2017/berichte/teilberichte/bund/Bun d 2017 23/Bund 201723 1.pdf.

RV. Regierungsvorlage. Bundesgesetz vom XX.XXXXX, mit welchem das Bundesgesetz betreffend Beschränkungen in der Verfügung über Gegenstände von geschichtlicher, künstlerischer oder kultureller Bedeutung (Denkmalschutzgesetz) geändert wird. 1275 der Beilagen zu den Stenographischen Protokollen des Nationalrates XVII. GP. Wien: Parlament, 1990. Accessed 20 September 2017, https://www.parlament.gv.at/PAKT/VHG/XVII/I/I 01275/imfname 266034.pdf.

RV. Regierungsvorlage. Bundesgesetz, mit welchem das Bundesgesetz betreffend Beschränkungen in der Verfügung über Gegenstände von geschichtlicher, künstlerischer oder kultureller Bedeutung (Denkmalschutzgesetz - DMSG) geändert wird. 1769 der Beilagen zu den Stenographischen Protokollen des Nationalrates XX. GP. Wien: Parlament, 1999. Accessed 20 September 2017, http://www.parlament.gv.at/PAKT/VHG/XX/I/I 01769/fname 140694.pdf.

Viebrock, J.N. Hessisches Denkmalschutzrecht. 3. neu bearbeitete Aufl., Stuttgart: Kohlhammer, 2007.

VLA. Leitlinien zur Archäologischen Denkmalpflege in Deutschland. Bonn: Verband der Landesarchäologen in der Bundesrepublik Deutschland, 2001. Accessed 22 September 2017, http://www.landesarchaeologen.de/fileadmin/Dokumente/Dokumente Verband/Leitlinien archaeo I Dkmpf.pdf.

WSVA. Ehrenkodex "Ethische Grundsätze für archäologische Fächer". Mannheim: West- und Süddeutscher Verband für Altertumsforschung e.V., 2010. Accessed 12 September 2017, http://www.wsva.net/fileadmin/wsva/dokumente/ehrenkodex 659 1.pdf.

\footnotetext{
${ }^{1}$ Belford \& Wait, Adding value.
} 


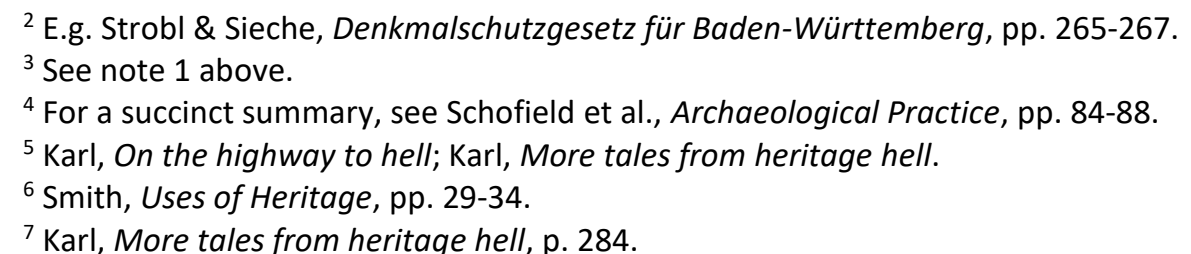

${ }^{8}$ The BDA explicitly started to interpret the provision of $\S 11$ (1) DMSG in this fashion in 1979 (as is evident from the then legal commentary on the law: Helfgott, Rechtsvorschriften, p. 83). While there is no earlier explicit evidence available on how it was actually interpreted before that date, it almost certainly started to be interpreted like this sometime in the period between late 1969 and the start of 1979. This is because as late as 1970, 'un-pre-permitted' excavations by non-professionals (that is, excavations which were started without a permit and the BDA only informed once the first discoveries were made, with the BDA then only permitting the continuation of the works under the provisions of (then) $\S 10$ (1) DMSG, which since has been renumbered as $\S 9$ (1) DMSG in the 1999 revision of the law) were still relatively common (as can be gathered from excavations reports from the time). Also, metal detectors first came into use in Austria at the turn from 1969 to 1970 (as can be established by finds reporting figures published by the BDA, see Karl, Archaeological responses); and the change in the interpretation of the applicability of $\S 11$ (1) DMSG was clearly a reaction to this.

${ }^{9} \mathrm{BDA}$, Richtlinien für archäologische Maßnahmen.

${ }^{10}$ All English translations of originally German texts in this article are by the author.

${ }^{11}$ "Voraussetzung für die Aufnahme jeglicher Grabungstätigkeiten »und sonstiger Nachforschungen an Ort und Stelle zum Zwecke der Entdeckung und Untersuchung beweglicher und unbeweglicher Denkmale" (\$11 Abs. 1 $D M S G)$ ist das Vorliegen eines bewilligenden Bescheides des Bundesdenkmalamtes gemäß \& 11 Abs. 1 DMSG." (BDA, Richtlinien für archäologische Maßnahmen, p. 6).

${ }^{12}$ See note 9 above, pp. 11-12.

${ }^{13}$ See note 9 above, pp. 12-15.

${ }^{14}$ However, several German state heritage agencies, based on almost exactly the same legal basis (a general excavation permit regime managed by the state heritage agency), explicitly claim such a privilege (see Strobl and Sieche, Denkmalschutzgesetz für Baden-Württemberg, pp. 265-267).

${ }^{15} \mathrm{Karl}$, On the highway to hell, pp. 112-113.

${ }^{16} \mathrm{Karl}$, More tales from heritage hell, pp. 284-287.

17 Karl, Obrigkeit und Untertan, pp. 7-11; Karl, The Freedom of Archaeological Research; Karl, Ich bin Hobbychirurg und Hobbypolizist.

18 „Die Nachforschung durch Veränderung der Erdoberfläche bzw. des Grundes unter Wasser (Grabung) und sonstige Nachforschungen an Ort und Stelle zum Zwecke der Entdeckung und Untersuchung beweglicher und unbeweglicher Denkmale unter der Erd- bzw. Wasseroberfläche dürfen nur mit Bewilligung des Bundesdenkmalamtes vorgenommen werden, soweit Abs. 2 und 9 nichts anderes vorsehen (Forschungsgrabung)."(§ 11 Abs. 1 DMSG).

${ }^{19}$ See note 9 above.

${ }^{20}$ See note 9 above, p. 6.

${ }^{21}$ „.... offenkundig den Beschränkungen dieses Bundesgesetzes unterliegen könnten“( 88 Abs. 1 DMSG).

22 "Die in diesem Bundesgesetz enthaltenen Bestimmungen finden auf von Menschen geschaffene unbewegliche und bewegliche Gegenstände (einschließlich Überresten und Spuren gestaltender menschlicher Bearbeitung sowie künstlich errichteter oder gestalteter Bodenformationen) von geschichtlicher, künstlerischer oder sonstiger kultureller Bedeutung (,Denkmale") Anwendung, wenn ihre Erhaltung dieser Bedeutung wegen im öffentlichen Interesse gelegen ist." (§ 1 Abs. 1 DMSG).

${ }^{23}$ See on this already Karl, Ein mikrolithischer Monumentalbau; Karl, Obrigkeit und Untertan, p. 7.

${ }^{24} \mathrm{RV}$, Regierungsvorlage, 1999, p. 39.

${ }^{25}$ See note 9 above, pp. 11-12.

${ }^{26}$ See note 9 above, pp. 11-12.

${ }^{27}$ "Die gesamte staatliche Verwaltung darf nur auf Grund der Gesetze ausgeübt werden." (Art. 18 Abs. 1 B-VG).

${ }^{28}$ Art. 18 B-VG establishes, as one of the 5 main constitutional principles of the Republic of Austria, the principle of the rule of law (for a short explanation of the main constitutional principles of Austria, see: https://www.parlament.gv.at/PERK/VERF/GRUND/index.shtml [accessed 4 April 2018]). This principle establishes that the state and its agencies must not act outside the law. By issuing permits for actions which 
require no state permit under the law, the BDA has breached this fundamental principle of Austrian constitutional law and has thus acted illegally. The outcome of the case discussed in this chapter proves this.

${ }^{29}$ See note 9 above.

30 Bazil et al., Das österreichische Denkmalschutzrecht. 2nd ed., pp. 16, 43-44.

31 Judge Pieler is well known to everyone in Austrian archaeological heritage management, because before taking up her current position as a Judge at the BVwG, she was responsible for legal matters regarding heritage management in the Austrian Ministry responsible for Cultural Affairs. It is thus also well known that, besides her law degrees, she also completed a Master's in archaeology.

32 The case was also referenced in my application and appeal; and has already been discussed in Karl, More tales from heritage hell, 285.

${ }^{33}$ Farka, Die Abteilung für Bodendenkmale, p. 10.

${ }^{34}$ Picker et al., Braucht Österreich ein Unterschutzstellungsprogramm, p. 285.

${ }^{35}$ See note 9 above, p. 6.

${ }^{36}$ See note 30 above, p. 112.

${ }^{37} \mathrm{RV}$, Regierungsvorlage, 1990, p. 1.

${ }^{38}$ CoE 1969, European Convention on the Protection of the Archaeological Heritage.

${ }^{39}$ See note 37 above, pp. 10-12.

${ }^{40}$ See note 4 above, p. 92.

${ }^{41}$ See note 9 above, pp. 11-12.

42 See note 16 above, pp. 289-292.

${ }^{43} \mathrm{RH}$, Bericht des Rechnungshofes: Bundesdenkmalamt.

${ }^{44}$ The estimate has been calculated using the higher figure of Farka Die Abteilung für Bodendenkmale, p. 10, of 52,000 'find spots' (points on a GIS), assuming an average site size of 1 hectare; rather than the lower and more recent figure by Picker et al., Braucht Österreich ein Unterschutzstellungsprogramm, p. 285, of 19,550 'sites' (area polygons on a GIS, often representing several of the 'find spots' counted by Farka). To get to $1 \%$ coverage of the Austrian landmass using Picker et al.'s lower figure, one would have to assume that each area polygon is on average at least 4.2 hectares in size, which, going by the reports in the Fundberichte aus Österreich and what they normally give in site sizes (normally under 1 hectare), is highly unlikely. Also, one can easily compare this with Bavaria (c. $85 \%$ the size of Austria), by checking the Bayerischer Denkmalatlas for Bodendenkmale (i.e. by switching off the built heritage and built ensemble layers). In Bavaria, there's currently slightly over 40,000 archaeological site polygons on the publicly accessible GIS (http://geoportal.bayern.de/bayernatlas-

klassik/fi hgoXp5oHfKeLjQ1G cyjE1EcMyrw45fQDTITqEnc BY73Gk8DbQ9uUinndTXv9kDHU2shxk8RATtjWRao GppJeCL6nbqc49kSoYoRZjSP2GA8tgqDIXYZfQ8dOsXD/fi fb/ZfQd4/oYoc4), and these cover less than $1 \%$ of the total landmass of Bavaria.

${ }^{45}$ Hebert and Hofer, Archäologie im Bundesdenkmalamt, p. 13.

${ }^{46}$ See note 15 above, pp. 115-124.

${ }^{47}$ See note 7 above, pp. 291-292.

48 https://finds.org.uk/ [accessed 5 December 2017].

49 See note 9 above.

50 See note 9 above.

51 Minimal teaching at e.g. the University of Innsbruck, BA in Archaeology: https://www.uibk.ac.at/service/c101/mitteilungsblatt/2014-2015/70/mitteil.pdf, 4 [accessed 5 December 2017], lectures normally taught by the BDA archaeologist responsible for the Tyrol.

Optional modules only ("if offered") e.g. at the University of Vienna, BA in Prehistoric and Historic Archaeology: http://www.univie.ac.at/mtbl02/2016 2017/2016 2017 131.pdf, 7 [accessed 5 December 2017], seminars normally taught by an academic archaeologist married to a BDA archaeologist.

Not included in the curriculum at all e.g. at the University of Graz, BA in Archaeology: https://www.uibk.ac.at/service/c101/mitteilungsblatt/2014-2015/70/mitteil.pdf [accessed 5 December 2017]. Occasionally, there have been optional courses on heritage management offered by the current Head of the Department of Archaeology of the BDA.

52 The DASV consists of representatives of the Archaeology Student Unions at all major Austrian, German and Swiss Universities teaching archaeology degrees, see http://www.dasv-ev.org/der-verein.html [accessed 5 December 2017].

53 The letter, which as one of its core demands states that modules on the subject should be taught by sufficiently qualified staff (implying that this is not the rule across all Universities), is available at 
https://www.academia.edu/21044077/Offener Brief des Dachverbands Arch\%C3\%A4ologischer Studierend envertretungen DASV e.V. zum Kulturg\%C3\%BCterschutz in der universit\%C3\%A4ren Lehre [accessed 5 December 2017].

54 e.g. Hebert, "Graue Schafe«; Hebert, Theorienbildung; Hebert, Denkmalwerte.

55 e.g. Fuchs 1991, Der latènezeitliche Waffenfund; Fuchs 1992, Der laténezeitliche Waffenfund.

56 e.g. Szemethy, Zur Situation der, illegalen Archäologie', p. 160-161.

57 Leskovar and Traxler, Archäologie in Oberösterreich, pp. 59-62.

${ }^{58}$ Bazil et al., Das österreichische Denkmalschutzrecht. 1st ed.; 2nd ed.

${ }^{59}$ Farka, Neufassung, p. 79.

60 "Das Fehlen einer theoretischen Diskussion über die Grundlagen der archäologischen Denkmalpflege beruht auf dem weitgehenden Konsens aller beteiligten Fachleute seit rund zwei Jahrhunderten“; Pollak, Zur Theorienbildung, p. 227.

${ }^{61}$ See note 6 above.

62 See note 60 above.

63 e.g. Art. 2.ii, CoE 1992. European Convention on the Protection of the Archaeological Heritage (revised).

${ }^{64}$ e.g. VLA, Leitlinien zur Archäologischen Denkmalpflege in Deutschland, p.4.

${ }^{65}$ Art. 3, CoE 1992. European Convention on the Protection of the Archaeological Heritage (revised).

${ }^{66} \mathrm{Karl}$, Obrigkeit und Untertan, pp. 6-7.

67 See note 30 above, p. 16.

$68 \mathrm{Karl}$, Warum es einer archäologischen Berufsethik.

${ }^{69}$ Leaving aside philosophical and epistemological considerations of whether 'the Truth' exists at all and/or can be conclusively found at all (of which it seems to me that only too few of us are sufficiently aware, too); discovery of 'the truth', that is, at least as accurate or 'verisimilar' an account of what 'actually' was the case in the past, generally remains the goal of academic archaeology, or at least its main self-regulatory principle. At the very least, the purpose of any academic study remains to avoid and/or remove anything positively 'false', 'erroneous', 'flawed', etc., both from any account (including the one itself gives) and the general academic consensus; necessarily implying that the discovery of the opposite of the 'false', which can, even if only as a gross simplification, be called 'the truth', was always and remains the ultimate goal of any academic endeavour.

${ }^{70}$ ClfA. Code of Conduct; WSVA, Ehrenkodex.

${ }^{71}$ Rączkowski, German School of Archaeology, p. 206.

72 In Austria, e.g. by the Staatsgrundgesetz, the constitutional law on the fundamental rights of all citizens, the Charter of the Fundamental Rights of the European Union, the International Covenant on Economic, Social and Cultural Rights (the treaty enshrining the Universal Declaration of Human Rights in international law; ratified by Austria in 1978), and most recently also the Faro Convention (ratified by Austria in 2015).

73 Karl, Obrigkeit und Untertan, p. 6; Karl, Freedom of Archaeological Research; Karl, Hobbychirurg und Hobbypolizist; cf. Davydov, „Jeder kann graben“?.

${ }^{74}$ This "long present" consists of the here and now and the reasonably accurately foreseeable future. Human activity in the "long present" thus consists of any activities already ongoing, about to commence, or at least in a planning stage, even though that planning may not be very specific and may not have progressed very far as yet. For instance, someone who acquires a metal detector is planning to eventually use it, even if he doesn't yet have any specific plans for when and where to use it for what specific purpose. While he may well still decide not to use it at all, or die unexpectedly before ever getting to actually use it; the fact that he buys it, of course with the intent to use it at some point in the foreseeable future, makes not just his purchase, but also its intended use in the foreseeable future, an activity in the "long present".

75 See note 57 above, pp. 59-66.

76 „...qua Gesetz im Interesse aller ... vor dem Zugriff aller...“; Lüth, Einführung, p. 102.

77 Tyler, Why People Obey the Law.

78 e.g. Leskovar and Traxler, Archäologie in Oberösterreich, p. 67; Hebert, "Graue Schafe«, pp. 143, 162-163.

${ }^{79}$ See more generally on this Tyler, Why People Obey the Law.

${ }^{80}$ See note 7 above, pp. 284-286.

${ }^{81}$ For the first hints at this misreading, see Farka, Neufassung, p. 79.

82 Schwammenhöfer, Ur- und frühgeschichtliche Fundstellen.

83 BDA, Richtlinien für archäologische Maßnahmen. 2. Fassung, p. 8.

${ }^{84}$ See note 43 above. 
85 „Nachforschungen, insbesondere Grabungen, mit dem Ziel, Bodendenkmäler zu entdecken, bedürfen der Genehmigung der Denkmalfachbehörde." (§ 22 HDSchG 2016).

${ }^{86}$ e.g. LfDH 2015, Richtlinien zur Grabungsdokumentation; LfDH 2017, Richtlinien zur Grabungsdokumentation; LfDH, Richtlinien Archäologie.

87 "I. Geltungsbereich der Richtlinien": „Bei Grabungen im Land Hessen, die auf einer Nachforschungsgenehmigung nach § 21 HDSchG bzw. einer denkmalschutzrechtlichen Erlaubnis nach § 16 HDSchG beruhen, liegen die Fundbearbeitungs- und Publikationsrechte beim Landesamt für Denkmalpflege Hessen. "; LfDH 2015, Richtlinien zur Grabungsdokumentation, p. 4.

${ }^{88}$ Viebrock, Hessisches Denkmalschutzrecht, p. 243.

89 LfDH 2015, Richtlinien zur Grabungsdokumentation.

90 See note 87 above.

${ }^{91}$ It is important to note here that this is not a question of plagiarism (i.e. passing off someone else's published work or ideas as one's own by not citing the original source it was taken from), since this permit condition did not concern published, but as yet unpublished material.

92 LfDH 2017, Richtlinien zur Grabungsdokumentation.

93 See note 5 above.

${ }^{94}$ e.g. Karl, Obrigkeit und Untertan, pp. 7-11; Karl, Freedom of Archaeological Research; Karl, Hobbychirurg und Hobbypolizist.

95 See note 6 above. 